\section{Use of Natural Lipids to Accelerate Ripening and Enhance Storage Life of Tomato Fruit with and without Ethephon}

\author{
Karim M. Farag and \\ Jiwan P. Palta ${ }^{2}$
}

\begin{abstract}
Additional index words. Lycopersicon esculentum Mill., color enhancement, senescence, respiration, shelf life, lysophosphatidylethanolamine, phosphatidylethanolamine, phosphatidyldimethylethanolamine dipalmitoyl
\end{abstract}

Summary. A natural lipid, lysophosphatidylethanolamine (LPE), was used as a tomato fruit ripening agent. The effect of this compound on hastening the ripening and on the defoliation of the Heinz 7155 processing tomato and the Glamour'freshmarket tomato (Lycopersicon esculentum Mill.) was compared to the effect of ethephon. Vines were sprayed to runoff in the field with a hand sprayer and fruits were harvested 2 weeks or 20 days later in a single harvest operation. LPE (100 mg liter $\left.{ }^{-1}\right)$ accelerated ripening of both processing and freshmarket tomatoes without defoliation. LPE-treated tomatoes had a better shelf life than the control or ethephon-treated fruit, whether they were harvested at the breaker, pink, or red stage of maturity. The combination of LPE and ethephon (100 $\mathrm{mg}$ liter $\left.^{-1}\right)$ enhanced tomato ripening without damaging the foliage, suggesting that LPE can mitigate the undesirable effects of ethephon on foliage and the fruit. The LPE-related lipid phosphatidyldimethylethanol-amine dipalmitoyl (PDED) also was able to enhance some aspects of keeping quality of tomato fruits, but was not able to

Department of Horticulture, University Of Wisconsin, Madison, WI 53706.

${ }^{1}$ Visiting Assistant Scientist.

Professor. enhance fruit ripening. Phosphatidylethanolamine was not as effective as LPE or PDED. It appears that the active molecule of this natural lipid is the lyso form. Our results provide evidence that LPE can enhance tomato fruit ripening and postharvest storage life of vine-ripe fruits and fruits picked at early ripeness stages.

$\mathrm{P}$ reduction of ethylene is associated with ripening of climacteric fruit, senescence, and plant response to stress under natural conditions. Ethephon [2-(chloroethyl) phosphoric acid] is an aqueous formulation that decomposes to ethylene and is used widely to maximize the yield of ripe tomato fruits in once-over harvesting operations (Liptay et al., 1981;Mutton, 1978). For example, in 1977, 80,000 acres of processing tomatoes in California were treated with ethephon (Sims et al., 1979). Ethephon advances ripening and allows one to control harvest time (Dostal and Wilcox, 1971; Iwahori et al., 1969; Robinson et al., 1968). However, ethephon application has several side effects, including rapid and extensive defoliation (Dunster, 1976) and induction of flower abscission (Phatak and Collin, 1970). Although loss of foliage makes mechanical harvesting much easier, the premature loss of foliage cover can result in sunscald damage to the fruit (Watterson, 1985) or overripe fruits, especially under hot summer conditions (Dunster, 1976). Ethephon induces chlorophyll degradation, which affects carbohydrate biosynthesis adversely (Mutton, 1978; Sims and Kashmire, 1972; Splittstoesser and Vandermark, 1971).

Recent results from our laboratory suggest that lysophosphatidylethanolamine (LPE) has the potential to enhance anthocyanin production in the skin of McIntosh apples (Malus domestics) and delay the loss of firmness of harvested apples (Farag and Palta, 199 la). We also have found that LPE is able to stimulate ethylene production in apple and cranberry fruit while keeping the respiration rate low (Farag and Palta, 1989). Furthermore, LPE treatment of attached and detached tomato leaves resulted in delaying their senescence (Farag and Palta, $1991 \mathrm{~b}$ ). LPE is a natural phospholipid currently being purified from egg yolk or brain tissue and could provide envi- ronmentally safe means for control of fruit ripening and leaf senescence.

This study was conducted to determine the influence of preharvest sprays of LPE on 1 ) promoting tomato fruit ripening, 2) enhancing tomato storage life, and 3) evaluating the phytotoxic effects of LPE on tomato foliage. Another objective was to compare the effect of LPE used in conjunction with ethephon on tomato fruit and leaf under the same field conditions.

\section{Materials and methods}

Plant material. Experiments were conducted using Heinz 7155 processing tomato, which is adapted to the Midwest, and Glamour freshmarket tomato.

Experiment 11989 season. Experimental plots were established in Burlington, Ill., by direct-seeding at the rate of $4.5 \mathrm{~kg}^{\mathrm{ha}}{ }^{-1}$ using Heinz 7155 tomatoes. Plots were under the Heinz program of cultural management. Soil at this location is silt loam. Nitrogen at the rate of $39 \mathrm{~kg} \mathrm{ha}^{-1}$ was applied as preplant broadcast from urea and sidedressed $72 \mathrm{~kg} \mathrm{ha}^{-1} \mathrm{~N}$ as diammoniun phosphate. The experimental design was a randomized complete block with two replications. Each replication consisted of a 5-m row of plants. Plants were sprayed with a hand sprayer on 7 Sept. to runoff with ethephon (Rhone Poulenc Ag Co., Lenexa, Kan.) at $1000 \mathrm{mg}$ liter $^{-1}$ or LPE (Sigma Chemical Co., St. Louis) at 100 $\mathrm{mg}$ liter ${ }^{-1}$. LPE solution was prepared in $1 \%(\mathrm{v} / \mathrm{v})$ ethanol. Control plots received either water or $1 \%(\mathrm{v} / \mathrm{v})$ ethanol. Ethephon was applied both with and without $1 \%(\mathrm{v} / \mathrm{v})$ ethanol. Factorial analyses of the data showed that differences due to ethanol were minimal and statistically insignificant. Thus, the rows receiving a treatment with and without ethanol were considered replications within the treatment. Plots were hand-harvested on 22 Sept. Observations were made on the visual appearance of tomato leaves after 4 days of field applications and at harvest. After harvest, fruits were sorted to three groups acceptable (firm and well-ripened fruits), green, and the remainder (spotted, molded, rotten). Acceptable tomatoes were subgraded into firm, soft, and the remainder (rotten, molded, spotted) after storage for 5 days in wooden crates at room temperature $(22 \pm 2 \mathrm{C})$. 
Experitment2 1990 season. Experimental plots were established on a silt loam soil at the Univ. of Wiscon sin-Madison campus farm using Heinz 7155 tomatoes. One-month-old seedlings were transplanted on 28 June 1990. Cultural practices were the same as in 1989. Plants were sprayed on 19 Sept. with a hand sprayer to runoff when $>50 \%$ of the fruits were at the breaker stage. Plants were sprayed with ethephon at $100 \mathrm{mg}$ liter ${ }^{-1}, \mathrm{LPE}$ at $100 \mathrm{mg}$ liter ${ }^{-1}$, commercial grade of $\mathrm{PE}$ at $2000 \mathrm{mg}$ liter $^{-1}, \mathrm{PDED}$ at 100 mg $\operatorname{liter}^{-1}$ (Sigma), or a combination of ethephon plus each of the mentioned chemicals. Ethanol $(2 \%, \mathrm{v} / \mathrm{v})$ was added to all solutions. Control plants were sprayed with ethanol $(2 \%$, $\mathrm{v} / \mathrm{v})$. Treatments were completely randomized in three replications. Each replication consisted of $3.6-\mathrm{m}$ rows (four plants). All fruits were harvested 20 days after spraying. Fruits were sorted into acceptable, green, and the remainder (rotten, spotted, molded); then all acceptable fruits were stored at room temperature $(22 \pm 2 \mathrm{C})$. Acceptable tomatoes were subgraded into firm, soft, and remainder after 1 week. The weight of each group was measured and calculated as a percentage of the total. We also followed the postharvest ripening of turning (breaker) and pink tomatoes stored at room temperature $(22 \pm 2 \mathrm{C})$. For this purpose, turning and pink tomatoes were sorted at harvest and were subgraded after 2 weeks of storage at room temperature $(22 \pm 2 \mathrm{C})$ into firm, soft, and remainder.

Experiment 31992 season. Experimental plots were established on silt loam soil in Oregon, Wis. Cultural practices were the same as in 1989 . Glamour fresh-market tomato was used in this experiment. Plants were sprayed when fruits were at the breaker stage with a hand sprayer to runoff on 8 Sept. and harvested 22 Sept. Treatments were randomized completely with 15 replications. Each replication consisted of one plant. Plants were sprayed with ethephon at 100 or 1000 mg liter ${ }^{-1}$, LPE at $100 \mathrm{mg}$ liter $^{-1}$, or a combination of ethephon (100 mg liter ${ }^{-1}$ ) plus LPE (100 mg liter ${ }^{-1}$ ). Ethanol $(2 \%, \mathrm{v} / \mathrm{v})$ was added to all solutions. Fruits were sorted into acceptable, green, and remainder (rotten, spotted, molded). Acceptable tomatoes were stored at room temperature $(22 \pm 2 \mathrm{C})$ for 6 days then sub-
Table 1. The effect of preharvest application of etbephon or lysophosphatidylethanolamine (LPE) on various grades of tomatoes at harvest (after 15 days of spray) and on the postharvest storage life of fruits after 5 days in aerated crates at room temperature $(22 \pm 2 C)$. Fruits were sprayed on 7 Sept. and harvested on 22 Sept. 1989. Values are means of two replications.

\begin{tabular}{|c|c|c|c|c|c|c|c|c|}
\hline \multirow[b]{2}{*}{ Treatments } & \multicolumn{3}{|c|}{$\begin{array}{c}\text { Fruit grade at harvest } \\
\text { (percentage of total weight) }\end{array}$} & \multicolumn{2}{|c|}{ Leaf appearance } & \multicolumn{3}{|c|}{$\begin{array}{c}\text { Subgrades } \\
\text { (percentage of total number) }\end{array}$} \\
\hline & Acceptable & Green & Remainder $^{y}$ & After 4 days & At harvest & Firm & Soft & Remainder \\
\hline Control & $17.6 \mathrm{~b}$ & $51.6 \mathrm{a}$ & $30.8 \mathrm{a}$ & Green & $\begin{array}{l}\text { Somewhat } \\
\text { yellow }\end{array}$ & $28.4 \mathrm{~b}$ & $35.7 \mathrm{a}$ & 35.9 a \\
\hline Ethephon & $50.1 \mathrm{a}$ & $13.1 \mathrm{~b}$ & $31.8 \mathrm{a}$ & Brown & Dead & $46.5 \mathrm{ab}$ & $30.4 \mathrm{a}$ & $23.2 \mathrm{a}$ \\
\hline LPE & $49.5 \mathrm{a}$ & $24.0 \mathrm{bc}$ & $26.5 \mathrm{a}$ & Green & $\begin{array}{l}\text { Somewhat } \\
\text { yellow }\end{array}$ & $55.2 \mathrm{a}$ & $38.8 \mathrm{a}$ & $6.1 \mathrm{~b}$ \\
\hline LSD & 19.6 & 21.8 & 16.3 & & & 20.9 & 11.2 & 12.9 \\
\hline
\end{tabular}

${ }^{2}$ Subgrades of acceptable grade after 5 days of storage at room temperature.

${ }^{y}$ Rotten, molded, spotted.

Mean separation in columns by LSD, $\mathrm{P}=0.05$. graded into firm $(15.7 \mathrm{~N})$, soft $(<15.7$ $\mathrm{N})$, and remainder. A McCormik (McCormik Fruit Inc., Yakima, Wash.) pressure tester was used to measure the pericarp firmness at the tropic of the fruit after peeling part of the skin. The weight of each group was measured and calculated as a percentage of the total.

\section{Results and discussion}

Experiment 1. Application of either LPE or ethephon promoted fruit ripening 15 days after application (Table 1). The proportion of acceptable fruit at harvest was greater for LPE or ethephon as compared to the control (Table 1). The percentage of green fruit was highest in the control. Both ethephon- and LPE-treated plants had significantly lower percentage of green fruit than the control. Although LPE treatment gave the lowest amount of rotten, molded, and spotted fruits, the differences among treatments were not significant (Table 1). Plants sprayed with ethephon showed leaf browning and irreversible shoot epinasty 4 days after application and the foliage was dead at harvest (Table 1). Plants sprayed with LPE were similar to control plants in visual appearance.

The quality of the firm fruits during postharvest storage was improved significantly by LPE as compared to the control (Table 1). Five days after harvest, LPE-treated fruits had a higher proportion of firm tomatoes as compared to control and a lower proportion of rotten, spotted, and molded fruits as compared to the ethephon and the control treatments. The undesirable fruit was only $6 \%$ of the total in the LPE treatment as compared to $23 \%$ and $36 \%$ in ethephon and control treatments, respectively.

Experiment 2. A combination of ethephon (100 mg liter ${ }^{-1}$ ) and LPE $\left(100 \mathrm{mg}\right.$ liter $\left.^{-1}\right)$ gave a higher percent-
Table 2. The effect of preharvest application of ethephon (E), lysophosphatidylethanolamine (LPE), commercial-grade phosphatidylethanolamine (PE), phosphatidyldimethylethanolamine dipalmitoyl (PDED) on the percentage of different grades of tomato fruit at harvest and on the postharvest storage life of acceptable grade. Fruits were sprayed on 19 Sept. and harvested on 9 Oct. 1990. Values are mean of three replications.

\begin{tabular}{|c|c|c|c|c|c|c|}
\hline \multirow[b]{2}{*}{ Treatments } & \multicolumn{3}{|c|}{$\begin{array}{c}\text { Fruit grades at harvest } \\
\text { (percentage of total weight) }\end{array}$} & \multicolumn{3}{|c|}{$\begin{array}{c}\text { Subgrades } \\
\text { (percentage of total weight) }\end{array}$} \\
\hline & Acceptable & Green & Remainder $^{y}$ & Firm & Soft & Remainder \\
\hline Control & $41.8 b$ & $37.3 \mathrm{ab}$ & $20.2 \mathrm{ab}$ & $23.0 \mathrm{c}$ & $6.8 \mathrm{a}$ & $70.3 \mathrm{ab}$ \\
\hline LPE & $49.8 \mathrm{ab}$ & $27.8 \mathrm{a}-\mathrm{c}$ & $22.4 \mathrm{ab}$ & $41.5 \mathrm{ab}$ & $4.4 \mathrm{ab}$ & $53.7 \mathrm{ab}$ \\
\hline $\mathrm{LPE}+\mathrm{E}$ & $54.5 \mathrm{a}$ & $20.1 \mathrm{c}$ & $19.6 \mathrm{ab}$ & $45.9 \mathrm{a}$ & $1.2 \mathrm{~b}$ & $52.9 \mathrm{~b}$ \\
\hline PDED & $46.5 \mathrm{ab}$ & $40.3 \mathrm{a}$ & $13.2 \mathrm{~b}$ & $29.1 \mathrm{bc}$ & $4.0 \mathrm{ab}$ & $67.0 \mathrm{ab}$ \\
\hline $\mathrm{PDED}+\mathrm{E}$ & $51.6 \mathrm{ab}$ & $28.6 \mathrm{a}-\mathrm{c}$ & $9.5 \mathrm{ab}$ & $31.8 \mathrm{a}-\mathrm{c}$ & $1.7 \mathrm{~b}$ & $66.5 \mathrm{~b}$ \\
\hline $\mathrm{PE}$ & $49.2 \mathrm{ab}$ & $30.5 \mathrm{a}-\mathrm{c}$ & $19.0 \mathrm{ab}$ & $28.3 \mathrm{bc}$ & $3.8 \mathrm{ab}$ & $67.9 \mathrm{ab}$ \\
\hline $\mathrm{PE}+\mathrm{E}$ & $44.3 \mathrm{ab}$ & $25.1 \mathrm{bc}$ & $30.6 \mathrm{a}$ & $31.0 \mathrm{a}-\mathrm{c}$ & $4.1 \mathrm{ab}$ & $64.9 \mathrm{ab}$ \\
\hline $\mathrm{E}$ & $44.3 \mathrm{ab}$ & 28.9 a-c & $26.8 \mathrm{a}$ & $20.8 c$ & $7.9 \mathrm{a}$ & $71.2 \mathrm{a}$ \\
\hline LSD & 10.9 & 14.5 & 12.7 & 16.5 & 5.0 & 17.8 \\
\hline
\end{tabular}

${ }^{2}$ Subgrades of acceptable grade after 1 week of storage at room temperature.

${ }^{y}$ Rotten, molded, spotted.

Mean separation in columns by LSD, $\mathrm{P}=0.0 .5$ 
age of acceptable fruit and a lower percentage of green fruit at harvest as compared to the control (Table 2). The postharvest storage quality of acceptable fruit was dramatically enhanced either by LPE or by a combination of LPE and ethephon as compared to the control and the ethephon alone (Table 2). In both of these treatments, the percentage of fruit rated as firm almost doubled (41.5\% and 45.9\%) as compared to the control or ethephon (23\% and 20.8\%) treatments. Both PE and PDED, either alone or in combination with ethephon, also gave a higher percentage of firm fruits as compared to the control and ethephon treatments, but these differences were not significant. A combination of LPE or PDED and ethephon gave significantly lower percentage of remainder fruit as compared to ethephon (Table 2).

Postharvest shelf life of the turning and pink tomatoes was dramatically affected by LPE and PDED treatments (Table 3). Turning and pink fruits were stored at room temperature $(22 \pm 2 \mathrm{C})$ after sorting at harvest. After 2 weeks of storage, more than half of the total amount of fruit was of firm quality in LPE, PDED, LPE plus ethephon, and PDED plus ethephon treatments, whereas the amount of firm fruits was only $38 \%$ and $28 \%$ in the control and ethephon treatments, respectively (Table 3). The percentage of undesirable fruit (rotten, spotted, molded) was significantly lower in LPE and PDED as compared to the control and ethephon. Furthermore, this percentage (remainder fruit) was significantly lower in LPE plus ethephon and
Table 4. The effect of preharvest application of ethephon (E) or lysophosphatidylethanolamine (LPE) on the percentage of different grades of Glamour tomato fruit at harvest and on the postharvest shelf life of acceptable grade. Fruits were sprayed on 8 Sept. and harvested on 22 Sept. 1992. Values are mean of 15 replications.

\begin{tabular}{lccccccc}
\hline & \multicolumn{3}{c}{$\begin{array}{c}\text { Fruit grades at harvest } \\
\text { (percentage of total weight) }\end{array}$} & & \multicolumn{3}{c}{$\begin{array}{c}\text { Subgrades } \\
\text { (percentage of total weight) }\end{array}$} \\
\cline { 2 - 4 } \cline { 6 - 8 } Treatments & Acceptable & Green & Remainder ${ }^{2}$ & & Firm & Soft & Remainder \\
\hline Control & $42.3 \mathrm{~b}$ & $27.3 \mathrm{a}$ & $30.1 \mathrm{ab}$ & & $0.3 \mathrm{c}$ & $41.2 \mathrm{~b}$ & $\mathbf{5 8 . 4 \mathrm { a }}$ \\
$\mathrm{LPE}$ & $54.6 \mathrm{a}$ & $22.8 \mathrm{ab}$ & $22.2 \mathrm{~b}$ & & $13.2 \mathrm{a}$ & $46.4 \mathrm{ab}$ & $40.4 \mathrm{~b}$ \\
$\mathrm{LPE}+\mathrm{E}^{y}$ & $50.6 \mathrm{ab}$ & $22.0 \mathrm{ab}$ & $27.5 \mathrm{ab}$ & & $6.6 \mathrm{~b}$ & $54.2 \mathrm{a}$ & $39.2 \mathrm{~b}$ \\
$\mathrm{E}^{y}$ & $50.9 \mathrm{ab}$ & $25.0 \mathrm{a}$ & $23.7 \mathrm{~b}$ & & $1.6 \mathrm{c}$ & $39.0 \mathrm{~b}$ & $59.6 \mathrm{a}$ \\
$\mathrm{E}^{\mathrm{x}}$ & $49.0 \mathrm{ab}$ & $15.6 \mathrm{~b}$ & $35.7 \mathrm{a}$ & & $0.0 \mathrm{c}$ & $40.2 \mathrm{~b}$ & $59.9 \mathrm{a}$ \\
LSD & 8.8 & 7.8 & 8.6 & & 3.6 & 11.1 & 11.4
\end{tabular}

${ }^{2}$ Rotten, molded, spotted.

${ }^{y}$ At $100 \mathrm{mg}$ liter ${ }^{-1}$

${ }^{*}$ At $1000 \mathrm{mg}$ liter.

Mean separation in columns by LSD, $\mathrm{P}=0.05$.

PDED plus ethephon as compared to ethephon alone.

Experiment 3. LPE treatment significantly enhanced the percentage of acceptable fresh-market tomato fruits at harvest as compared to control (Table 4). Ethephon (1000 mg liter $\left.{ }^{-1}\right)$ significantly reduced the percentage of green tomatoes at harvest as compared to the control and ethephon at 100 $\mathrm{mg}$ liter $^{-1}$. Ethephon (1000 mg liter ${ }^{-1}$ ) resulted in significantly higher percentage of remainder (rotten, molded, spotted) tomatoes as compared to LPE and ethephon at $100 \mathrm{mg}$ liter $^{-1}$ (Table 4).

LPE significantly enhanced the shelf life of fresh-market tomatoes (Table 4). LPE alone or in combination with ethephon at $100 \mathrm{mg}$ liter $^{-1}$ resulted in significantly higher percentage of firm tomatoes following 6 days of storage at room temperature $(22 \pm 2 \mathrm{C})$ after harvest. Both LPE treatments gave lower percentage of

Table 3. Subgrades of turning and pink tomato fruits (sorted at has-vest) as influenced by preharvest treatment of ethephon, LPE, commercial grade of PE or PDED after storage for 2 weeks at room temperature during 1990 season. Values are mean of three replications. Abbreviations are same as in Table 2.

\begin{tabular}{|c|c|c|c|}
\hline \multirow[b]{2}{*}{ Treatments } & \multicolumn{3}{|c|}{ Grade (percentage of total weight) } \\
\hline & Firm & Soft & Remainder $^{2}$ \\
\hline Control & $37.7 \mathrm{de}$ & $16.6 \mathrm{a}$ & $45.7 \mathrm{a}-\mathrm{c}$ \\
\hline LPE & $59.9 \mathrm{ab}$ & $11.9 \mathrm{ab}$ & $28.2 \mathrm{~d}$ \\
\hline $\mathrm{LPE}+\mathrm{E}$ & $56.4 \mathrm{ab}$ & $10.6 \mathrm{ab}$ & $33.0 \mathrm{dc}$ \\
\hline PDED & $64.3 \mathrm{a}$ & $8.4 \mathrm{ab}$ & $27.4 \mathrm{~d}$ \\
\hline $\mathrm{PDED}+\mathrm{E}$ & $51.8 \mathrm{a}-\mathrm{c}$ & $11.0 \mathrm{ab}$ & $37.2 \mathrm{~b}-\mathrm{d}$ \\
\hline PE & $46.5 \mathrm{~b}-\mathrm{d}$ & $4.5 \mathrm{~b}$ & $49.1 \mathrm{ab}$ \\
\hline $\mathrm{PE}+\mathrm{E}$ & $39.4 \mathrm{c}-\mathrm{e}$ & $8.1 \mathrm{ab}$ & $52.5 \mathrm{ab}$ \\
\hline $\mathrm{E}$ & $28.0 \mathrm{c}$ & $17.0 \mathrm{a}$ & $55.0 \mathrm{a}$ \\
\hline LSD & 14.0 & 9.1 & 15.6 \\
\hline
\end{tabular}

${ }^{2}$ Rotten, molded, spotted.

Mean separation in columns by $L S D, \mathrm{P}=0.05$. rotten, molded, and spotted (remainder) fruits (Table 4). Thus, the percentage of acceptable fruit (firm + soil) was almost $20 \%$ higher in the two LPE treatments compared to the control.

The results of our studies suggest that a natural lipid, lysophosphatidylethanolamine (LPE), can enhance ripening and shelf life of processing and fresh-market tomato fruit. These results further suggest that LPE may be able to mitigate the possible undesirable effects of ethephon on foliage and fruit storability. Although a related molecule, PDED, was able to give some of the desirable effects on the shelf life, this molecule was not effective in accelerating ripening. Furthermore, PE was not as effective as LPE. Thus, LPE appears to be the mosteffective molecule, although related molecules have some similar effects on tomato fruit.

Fruits picked at early ripeness stages and ripened off the vine have poorer flavor than fruit picked tableripe (Bisogni et al., 1976; Jones and Scott, 1983). In recent years, demand for vine-ripe fruit has increased. However, vine-ripe fruit is more subject to spoilage during postharvest handling and marketing. Our results (Table 4) suggest that LPE can enhance shelflife of vine-ripe fruit.

We do not know the exact mechanism by which LPE mediates fruit ripening and enhances fruit storage life. Our recent results show that LPE enhances ethylene production in fruit tissue (Farag and Palta, 1989 ). In these studies, we found that, while ethylene production is stimulated, the respiration rate remains unchanged by LPE treatment. Polygalacturonase (PG) has been suggested to be responsible for 
ripening-associated fruit softening (see Fisher and Bennett, 1991 for review). Recently, we have obtained evidence that LPE can inhibit the activity of PG extracted from tomato fruit (Farag and Palta, 1992). Furthermore, we also have evidence that LPE can retard tomato leaf senescence (Farag and Palta, 199 lb). Thus, LPE may be able to maintain fruit quality by keeping the fruit respiration low, by inhibiting the activity of enzymes involved in fruit softening, and by retarding senescence.

\section{Literature Cited}

Bisogni, C.A; G. Armbuster, and P.E. Brecht. 1976. Quality comparisons of room ripened and field ripened tomato fruits. J. Food Sci. 41:333-338.

Dostal, H.C. and G.E. Wilcox. 1970. Chemical regulation of fruit ripening of field grown tomatoes with (2-chloroethyl) phosphonic acid. J. Amer. Soc. Hort. Sci. 96: 656-660.

Dunster, K.W. 1976. Pros and cons of using Ethrel. Amer. Veg. Grower 24:15 16.

Farag, K.M. and J.P. Palta. 1989. Stimulation of ethylene production by urea, thidiazuron and lysophosphatidylethanolamine and possible sites of stimulation. Plant Physiol. 89:568 (Abstr.)

Farag, K.M. and J.P. Palta. 1991a. Use of lysophosphatidylethanolamine, a natural lipid, as an aid for fruit ripening and improving keeping quality. Proc. 17th Ann. Mtg. of the Plant Growth Regulat. Soc. Amer. p. 135137.

Farag, K.M. and J.P. Palta. 1991b. Use of lysophosphatidylethanolamine, a natural lipid, to delay tomato fruit and leaf senescence. HortScience 26:67. (Abstr.)

Farag, K.M. and J.P. Palta. 1992. Evidence for a specific inhibition of the activity of polygalacturonase by lysophosphatidylethanolamine in tomato fruit tissue: Implication for enhancing storage stability and reducing abscission of the fruit. Plant Physiol. 99:54 (Abstr.)
Fisher, R.L. and A.B. Bennett. 1991. Role of cell wall hydrolyses in fruit ripening. Annu. Rev. Plant Physiol. Plant Mol. Biol. 42:675-703.

Jones, R.A. and S.J. Scott. 1984. Genetic potential to improve tomato flavor in commercial $\mathrm{F}_{1}$ hybrids. J. Amer. Soc. Hort. Sci. 109: 318321.

Iwahori, S., S. Ben-Yeboshua, and J.M. Lyons. 1969. Effect of 2-chloroethanephosphonic acid on tomato fruit development and maturation. Bioscience 19:49 50 .

Liptay, A., C.A. Jaworski, and S.C. Phatak. 1981. Effect of tomato transplant on tomato yield, fruit size and number. Can. J. Plant Sci. 61:413-415.

Mutton, L.L. 1978. Switched-on ripening by Ethrel on tomato crops. Agr. Gaz. New South Wales. Aug. p. 3536.

Phatak, S. C. and G.M. Collin. 1970. Concentration of tomato fruit ripening with Ethrel. Hort. Res. Inst. Ont. Rpt. for 1960 1970. p. 86-90.

Robinson, R.W.H. Wilczynski, F.G. Dennis, Jr., and H.H. Bryan. 1968. Chemical promotion of tomato fruit ripening. Proc. Amer. Soc. Hort. Sci. 93:823-830.

Sims, W.L. and R.F. Kashmire. 1972. Ethephon response favorable on fresh market tomatoes...pre - and postharvest studies show earlier production and more uniform ripening. Calif. Agr. 26:3-4.

Sims, W.L., M.P. Zobel, D.M. May, R.J. Mullin, and P.P. Osterli. 1979. Ripening agents: In Mechanized growing and harvesting of processing tomatoes. Div. of Agricultural Sciences, Univ. of California, Berkeley, Lflt 2686. p. 31.

Splittstoesser, W.E. and J.S. Vandemark. 1971. Maturation, fruit size and yield of tomatoes treated before harvest with (2chloroethyl ) phosphoric acid. J. Amer. Soc. Hort. Sci. 96: 564567.

Watterson, J.C. 1985. Tomato diseases: A practical guide for seedsmen, growers and agricultural advisors. Petoseed Co., Inc. p. 43 . 